\title{
THE CATHEDRAL OF ANTIGUA GUATEMALA, A COLONIAL PAINTING, CA. $1718 .^{1}$
}

\author{
Eva S. LAMOTHE.
} New Orleans Museum of Art.

This article will examine and attribute a new date to the colonial oil painting of the construction of the third cathedral in Antigua Guatemala, ${ }^{2}$ (plate 1). This oil panting was first discusser and dated in 1969 in a short monograph by Luis Luján Muñoz and in an article by Xavier Moyssén. ${ }^{3}$ The painting, oil on canvas, measuring $1.65 \times 1.57 \mathrm{~m}$, is unsigned and undated. ${ }^{4}$ The specific subject matter of the painting is the unfinished cathedral of Antigua Guatemala, which was inaugurated in November, $1680 .^{5}$ The unfinished cathedral takes up approximately two thirds of the canvas. The remaining third of the canvas is devoted to the Plaza Mayor in front of the cathedral. Antigua, or Santiago de los Caballeros, the city's colonial name, was the colonial capital of the Captaincy General of Guatemala, which, in addition to Guatemala, included most of present-day Central America.

The provenance of the painting is unknown, but it is presently located in Mexico. No document has been located in either Guatemala, Mexico or Spain that accounts for the transfer of this painting from Guatemala to

\footnotetext{
${ }^{1}$ This article originated as a chapter in my M.A. thesis in Art History at Tulane University, 1982, Vaults and Domes in Colonial Antigua Guatemala, ca 1650-1773. The thesis examines the style, construction and decoration of colonial vaults in Guatemala.

2 The first cathedral was located in the Valley of Almolonga. It was founded in 1529. In 1541 the capital of the Captaincy General of Guatemala was destroyed in a flood and the capital moved to present-day Antigua. The second cathedral was founded here in 1543. The third cathedral, also located in Antigua, or Santiago de los Caballer os, its colonial name, was initiated in 1669. See María Concepción Amerlinck, Las Catedrales de Santiago de los caballeros de Guatemala, Universidad Nacional Autónoma de México, Instituto de Investigaciones Esstéticas, México, 1981 , pp. 20, 25, 65 .

${ }^{3}$ Luis, Luján Muñoz, La Plaza de Santiago de Guatemala hacia 1678, Guatemala, C.A. Instituto de Antropología e Historia, Ministerio de Educación, Publicación Especial, no. 3, 1969; and Xavier Moyssén, "Como se construía una catedral en el siglo XVII" in Boletín del Instituto Nacional de Antropología e Historia, México: Secretaría de Educación Pública vol. 38, dic. 1969, pp. 1-10.

4 The painting was located in, la Galería de Antiguedades La Granja, Mexico City, until recently.

${ }^{5}$ Ernesto Lemoine Villicaña, "Historia sucinta de la construcción de la catedral de Guatemala escrita en 1677 por Don Gerónimo de Betanzos y Quiñones", in Boletín del Archivo General de la Nación, no. 3, México, $1961 \mathrm{~m}, \mathrm{p} .414$.
} 
México. Xavier Moyssén and Luis Luján Muñoz suggested that the painting may have been brought from Guatemala to Mexico in 1682 when the Bishop of the Captaincy General of Guatemala, Juan de Ortega y Montanes, was transferred from Antigua to Michoacan. ${ }^{6}$ Bishop Ortega had participated in the planning of the cathedral and inaugurated it in 1680 in celebration of the birthday of king Carlos II and his marriage to a French Princess. ${ }^{7}$

Amerlinck, in a recent publication, discounts this theory and suggests that the oil painting may be one of several paintings that Antonio Ramirez was commissioned to paint in 1678 . These paintings were to be sent to New Spain and the Real Consejo de Indias. ${ }^{8}$

In their 1969 publications, Moyssén and Luján attributed the painting to an anonymous artist. Luján, however, in a later publication attributed the painting to artist Antonio Ramírez Montufar. ${ }^{9}$ The painting was dated 1677 by Moyssén and 1678 by Luján and Amerlinck. ${ }^{10}$ Moyssén and Luján based their dates on the same document, a report written to the king in Spain by the obrero mayor of the cathedral, Gerónimo de Betanzos y Quiñones. This document is dated November 3, $1677 .{ }^{11}$ In this report to the king regarding the status of the construction of the cathedral in 1677 , Betanzos stated, among other things, that, out of a total 62 vaults, only 52 had been constructed. ${ }^{12}$ Moyssén believed there was a direct relationship between the 1677 document and the painting and that the painting was made to illustrate the document. ${ }^{13}$ Luján, however, noted that only one vault was under construction in the painting, not ten as the 1677 document

\footnotetext{
"Moyssén, "Como se construía una catedral en el siglo XVII", p. 5, Luján, La Plaza de Santiago de Guatemala hacia 1678, p. 8.

${ }^{7}$ Lemoine Villicaña, op. cit., p. 414.

${ }^{8}$ Amerlinck, Las Catedrales de Santiago de los Caballeros de Guatemala, $\mathrm{p} .11$, foot note 5 , p. 12. M. Díaz also mentions Ramírez as the painter of pictures of the cathedral, M. Díaz, $L a$ r 0 mántica ciudad colonial, Guatemala, Tipografía Nacional 1927, p. 30.

${ }^{9}$ Luján Muñoz, Luis, Sintesis biográfica del Maestro Mayor de Arquitectura: Diego de porres (1677-1977), Guatemala, C A., Imprenta y Litografia de la Riva Hnos., 1977, p. 28. This is the same Antonio Ramírez that Amerlinck refers to. Amerlinck questions why Luján Muñoz added "Montufar" to the name of the artist Antonio Ramírez, Amerlinck, Las Catedrales, pp. $11,12$.

${ }^{10}$ Moyssén, "Como se construía . ". " p. 4, 5; Luján Muñoz, La Plaza. . ., p. 5; Amerlinck, Las Catedrales, p. 12

${ }^{11}$ This document was first published by Lemoine Villicaña, "Historia sucinta de la construcción de la catedral de Guatemala...", p. 417-430, and later by Luján Muñoz, La Plaza., ., pp. 35-44.

12 Villicaña, "Historia sucinta....", p. 414; Luján, La Plaza, p. 39.

${ }^{13}$ Moyssén, "Como...," p. 3 .
} 
indicated (plate 1). Luján, therefore, dated the painting 1678, pointing out that the activity in the painting appeared to be further advanced in the painting than in the document ${ }^{14}$ Amerlinck dated the painting 1678, linking it to the paintings that Ramirez was commissioned to paint in that year.

Amerlinck also felt the panting showed the cathedral immediately prior to its conclusion. ${ }^{15}$

Luján's observation that the construction of the cathedral was further advanced in the painting than in the 1677 document is indeed correct, but an examination of the painting, the 1677 document, a plan of the cathedral in $1773^{16}$ and the construction activity that the earthquakes after the 1680 inauguration made necessary, strongly indicates that an even later date than the 1678 date suggested by Luján, should be given to the painting. Earthquakes which cause architectural damage still occur regularly in Antigua. Serious earthquakes causing great damage to Antiguan architecture in general and to the cathedral in particular, during the colonial period, occurred in 1689, 1717, 1751 and $1773 .{ }^{17}$ The painting is cleary from the colonial period and could show the cathedral after one of these earthquakes. After a series of particularly serious quakes in 1773, the king, Carlos III, ordered the capital of the Captaincy General to be transferred from Antigua to the Valle de las Vacas. ${ }^{18}$ Before attributing a new date to the painting, it it necessary to again examine its contents.

The large painting (plate 1), meastring $1.65 \times 1.57 \mathrm{~m}$, is filled with different activities: a mix of Spaniards, indians, mestizos and mulattos are mixing in the Plaza Mayor in front of the cathedral. Some of these people are selling produce or other goods in the market; other are talking or moving around in the Plaza. There are some rather humorous and casual events rendered in the sytle of Northern European genre painting: a large dog is scratching his ear with one paw and a man is chasing a black youth

\footnotetext{
14 Luján, La Plaza, p. 8, foot note 2.

15 Amerlinck, Las Catedrales, p. 12 .

${ }^{16}$ D. J. Villacorta, Historia de la Capitania General de Guatemala, Guatemala, 1944, p. 318, published the plan dated 1773

17 Verle Lincoln Annis, The Architecture of Antigua Guatemala, 1543-1773, Guatemala, C.A., University of San Carlos, 1968, p. 11; Sidney David Markman, Colonial Architecture of Antigua Guatemala, Philadelphia, The American Philosophical Society, 1966, p. 114; Amerlinck, Las Catedrales, p. 159

${ }^{18}$ Carlos III ordered the capital to be moved on July, 1775. The foutth and last cathedral of Guatemala was not founded until November 22, 1779, howevet. Amerlinck, Las Catedrales, p. 173.
} 
with a large stick. The location of the viewer, who hovers in mid-air, is also typical of the Northern European style. Two carriages are shown in the painting. The one on the right, entering the plaza, is followed by several priests. This carriage contains an ecclesiastical dignitary, probably the bishop. ${ }^{19}$ The carriage on the left holds women and children. The painting is pulsating with everyday activities. On the roof of the cathedral several musicians are playing their instruments and the bells in the church tower to the left of the cathedral are chiming. In the upper balcony of the Capitania General, located on the right side of the Plaza Mayor, several men, probably political leaders, are looking down onto the activity in the market. One man with gray hair is set apart from the others by having more detailed facial features and what appears as a golden decoration on his shoulder. This man appears to be smiling. In the foreground is a fountain from which both people and animals help themselves to water. In the left entrance door to the cathedral, a man, dressed in black and white, is separated from his surroundings by being larger and posing in a more nearly frontal position than any of the workers in the cathedral. This man appears to demand attention and to have a supervisory position.

However, despite the people in the plaza, the main attention in the painting is focused on the cathedral and the construction activity going on on its roof, facade and southern side, i.e. the right wall of the building. Two thirds of the canvas is taken up by the cathedral. The cathedral consists of a central nave with a clerestory, two sides aisles and two rows of chapels on each side of the central nave. On the south side, two bays protrude outside this rectangular plan in both the east and west (the facade faces west, so the south side of the cathedral is located on the right in the painting). The central nave and the rows of chapels are marked with numbers which are identified in a key in the upper left corner of the painting (this key is placed in an appendix at the end of this text). In the key the bays are identified by the saint the chapel is dedicated to or the location within the church of the bay. The surrounding architectural structures are also identified in this key. None of the people are identified in a similar fashion. The key explains only architectural details, mainly vaults, or the activity pertaining to the construction of these vaults. The fact that two thirds of the canvas is dedicated to the cathedral indicates that the painting was made in order to illustrate an important phase in

\footnotetext{
${ }^{19}$ The Bishop's seat was the highest church position in Antigua until 1743, when the cathedral became the seat of an archbishop.
} 
the history of the cathedral. All the vaults are laboriously identified in the key. Other elements of the cathedral, e.g. the facade or the bell tower are excluded from the key. The importance of the people seems to be to indicate their social function in the city of Antigua, not their identity, since they remain anonymous. The people are shown as political leaders, ecclesiastical leaders, construction workers, priests, women and children from the upper class as well as common people, men, women and children, mixing in the market place.

The cathedral is seen from above and the back and central nave of the church are tilted upwards so that the viewer can survey all the vaults of the cathedral. This view is unrealistic and further points out that it is the vaults of the cathedral that are of main interest for the artist.

Scaffolding, appearing to be in the process of construction in the painting, and a large number of construction workers identify three main areas of construction activity: the facade, the octagonal drum of the central nave and the side and back of the vaults protruding outside the rectangular church plan as a continuation of the facade. The key identifies these areas as the facade (11), cimborrium (6) and Sagrario (31) (see the appendix). The facade and cimborrium drum, although in an unfinished state, both have stucco decorations. The facade has stucco decorations on the pedestals under the double columns flanking each entrance to the cathedral. There is a large coat of arms over the central entrance and the niches and windows are decorated beneath, as well as above, these elements. The second cuerpo of the facade has volutes that appear to be broken off rather than unfinished in construction (compare plate 2 of a 1784 drawing of the facade). In general, unfinished brick construction leaves "clean" and sharp edges where the last brick is laid and the bricks would be laid in straight rows starting from the bottom and continuing upwards until the design is finished. In the painting the volutes have jagged ends, as if part of the volutes of the facade had broken off. The volute terminates in the center of its own design with a jagged edge going from top to bottom.

The octagonal drum has stucco decorations below, around and above its rectangular windows. At the very point where the drum ends, just above the windows, the kind of broken pediment in stucco-brick that is so popular over windows, niches and entrances in Antiguan architecture, can be seen. The interior surfaces of the cimborrium were decorated by December 24, 1679, two years after the 1677 date attributed the painting 
by Moyssén. ${ }^{20}$ It is likely that the exterior of this cimborrium was decorated after its interior because the cathedral needed to be in use prior to its total completion. The spherical dome over the circular drum, marked 3, is also clearly decorated. ${ }^{213}$ Thus, the decorated surfaces of the exterior and interior of the cimborrium indicate that the painting should be dated later than 1677. There is however, another reason in connection with the cimborrium which indicates that the painting was made at a date different from the 1677 document. There is no centering used in the construction of the octagonal dome over the crossing. The 1677 document in detail describes how Gerónimo de Betanzos y Quiñones, risking his life, went nine "leguas" outside the city in order" to get wood that could be used for the centering of all the vaults. ${ }^{21 \mathrm{~b}}$ In the painting the workers are using scaffolding on the exterior of the drum.

There are no windows in the southern lateral wall, except above the lateral entrance. Here two windows are added in a wall that extends slightly above the vaults and connects with the clerestory where a cross wall runs into the central nave. Two workers appear to be working on this extended piece of the wall. On the ground below a group of workers is busy. The small house next to the workers is the Sacristan's house (37). In front of the facade there is a lot of activity going on by the front steps leading into the church. To the left of the cathedral is the Bishop's Palace (35). This structure includes a patio with a fountain. A horse, or mule, is standing outside one of the buildings that stretch towards the end of the block.

The broken, rather than unfinished, second cuerpo of the facade with its jagged edges, the making of scaffoldings, rather than the use of centering, the attention given the roofing of the cathedral, and the stucco decorations on the facade and octagonal drum up to the very points where the brick work terminates in jagged edges, indicate that the painting does not show the cathedral just prior to its conclusion of ca. 1680 , but at some later date when damage had ocurred to the already finished and decorated church. This damage may have been caused by one of the several serious earthquakes that caused repairs to be curried out on the cathedral. Serious earthquakes courred in $1689,1717,1751$ and $1773 .^{22}$

\footnotetext{
${ }^{20}$ See Amerlinck, Las Catedrales, p. 129, for the date of the interior decoration of the cimborrium.

2la Betanzos in 1677 described the decoration of this vault, see Lemoine Villicaña, "Historia sucinta...", p. 427. The interior of this vault was decorated with stucco relief sculptures in polychrome. See also number 32 in the key of the painting. In the painting the interior of the dome is exposed and placed on the drum of which we only sec the exterior.

$21 \mathrm{~b}$ Villicaña, pp. 423-24

${ }^{22}$ Annis, The Architecture ., p. 11; Markman, Colonial Architecture., p. 114; Ameilinck, Las Catedrales, p 159.
} 
The plan of the cathedral indicates that the painting would not have been painted after the 1751 or 1773 earthquakes. The plan of the church in the painting indicates that the painting was painted before 1743. In 1743 the Socorro Chapel, marked 24 in the painting (plate 1) and located as the third vault starting in the east in the row of chapels on the right side of the cathedral, was moved to the area that the rear bell tower occupies in the painting. ${ }^{23}$ Its post- 1743 location can be found in the 1773 plan of the cathedral (plate 3) where the Socorro Chapel is marked with the number 2; located in the northeastern corner of the chuch plan, the Socorro Chapel now takes up four bays. The central bay of the post-1743 Socorro Chapel had a media naranja on pendentives that was topped with a lantern in the shape of a crown. ${ }^{24}$ It was covered with tiles and had eight windows. The post-1743 Socorro Chapel can still be located in its northeastern corner of the church plan, even though the dome over the central bay has collapsed (plate 4). In the painting, the Socorro Chapel is still in its pre-1743 location and consists of one bay with a low spherical vault. The painting must consequently be painted before 1743 and we will concern ourselves only with the earthquake damage caused in 1689 and 1717 , the only two major earthquakes prior to 1743 .

The damage caused by the 1689 quake was light; only a few arches developed cracks. ${ }^{25}$ The damage in the quake of 1717 was serious, however. Among colonial writers, Arana describes the damage in most details: the cimborrium in the crossing came down and the vault over the entrance to the Sagrario, the arch in front of the choir, the facade and the tower were damaged ${ }^{26}$ In the painting we have already identified three points of construction: the cimborrium, the facade and the Sagrario. These three areas were also the areas with the greatest damage in 1717. The Sagrario, in the painting, does not appear to be in ruins but consists of only three bays (plate 1) including the last vault, marked 31, in the right hand row of chapels and the two vaulted bays to the right of the vault marked 31 . Number 31 in the key in the upper left corner of the painting identifies the Sagrario (see the appendix, number 31). In the key the Sagrario is described as having seven bays, i.e. four more bays than the painting illustrates. In 1677 the Sagrario seems to have had only three bays: because in that year Betanzos compares the size and shape of the Sagrario to that

\footnotetext{
${ }^{23}$ Annis, The Architecture, p. 51, citing Juarros, II, p. 250.

${ }^{24}$ Amerlinck, Las Catedrales, p. 134.

${ }^{25}$ Annis, The Architecture, p. 52; Markman, Colonial Architecture, p. 114; Amerlinck, Las Catedrales, pp. 67, 159

${ }^{26}$ Amerlinck, Las Catedrales, p. 164.
} 
of the Sacristy, ${ }^{27}$ which in the 1773 plan (plate 3) has three bays: the vault marked 19 and the two vaulted bays on both sides of it. At some point the Sagrario consequently had four bays added to the original three bays. This is demonstrated in the 1773 plan (plate 3) in which the Sagrario has seven bays. The scaffolding on the front side and back walls of the Sagrario in the painting indicates that the missing four bays were to be repaired, or possibly constructed for the first time, when the painting was made. The key may in this instance project the planned size of the Sagrario, which has not been repaired yet or is about to be enlarged for the first time:

Reports describing the repairs of the cathedral initiated after the earthquake of 1717 state that repairs were started on April 6, 1717. ${ }^{28}$ The repairs included the making of scaffoldings, the taking down of the cimborrium, the repair of leaks, the lowering of the first cuerpo of the facade and the repair of the main entrance and the towers. ${ }^{29}$ Further repairs included the Sacristan's house. The Sacristan's house is numbered 37 in the painting and next to this small house is a group of workers. The repairs continued until the third of February, 1719, when the Cabildo reported to the king, Philip V, that the cathedral was totally repaired..$^{30}$

It appears now that the construction activity in the painting coincides with the areas of the cathedral that were damaged in 1717 and repaired in 1718-1719: the facade, cimborrium, Sagrario and Sacristan's house. Notice also that some workers are painting the rear vaults and that these vaults have been decorated with the false decorative stucco ribs that Markman was the first to notice in Antiguan vaulting. ${ }^{31}$ The painted vaults are white and the vaults may be covered with a last coat of whitewash that would help prevent leaks. All vaults in Antigua were plastered white on the exterior ${ }^{32}$ This probably also served as waterproofing. Records indicate that on April 6, 1718, the vaults of the cathedral were treated against leaks. On this days scaffoldings were also made to take down the cimborrium, which was severely damaged. In the painting, many workers appear more preoccupied with the scaffoldings than with the cathedral behind the

\footnotetext{
${ }^{27}$ Lemoine Villicaña, "Historia. ...", p. 427.

28 Amerlinck, Las Catedrales, p. 165.

29 The tower's referred to were part of the facade. They were constructed in 1684-86, but came down in the earthquake of 1717 . They were tebuilt because they appear in prints and drawings from as late as the mid-19th century. Amerlinck, Las Catedrales, p. 113.

${ }^{30}$ Amerlinck, Las Catedrales, p. 165. It is possible that this is an exageration and that repairs continued on the cathedral until 1722.

${ }^{31}$ Markman, Colonial Architecture, p. 37

32 Markman, Colonial, p. 34.
} 
scaffolds. In at least one instance, men are carrying a beam towards the cimborrium. This beam appears identical to the beams used in the scaffoldings.

The above observations strongly speak for a new and later than ca. 1677 date for the painting. There is, however, additional evidence that this painting must be dated considerable after 1677 . In a previous paragraph of this paper it was demonstrated that the painting was painted before 1743. A pre-1743 date is also indicated by the explication in the key for the structure located to the left of the cathedral. We refer to this building as the Archbishop's Palace, but the key describes this building as the Bishop's Palace (see number 35 of the key in the appendix). In 1743 Antigua became the seat for an Archbishop for the first time. ${ }^{33}$ Prior to this date the highest church dignitary in Antigua and Guatemala had been the bishop. The Bishop's Palace as it looks in the painting, with structures covering the entire length of the block, was not begun until 1706, 29 years after the date previously attributed to the painting. ${ }^{34}$ Begun in 1706, the Bishop's Palace was finished in October of 1711 and then included fountains, servant's quarters and stables which together with the palace covered the length of the block otherwise occupied only by the cathedral. ${ }^{35}$ The only construction carried out on the place after 1711 took place after the earthquake of 1717. The 1717 damage to the palace has not been described in detail by any colonial writer and Ximénez and Arana contradict each other on this issue. ${ }^{36}$ Ximénez refuted Arana's statement that the palace was in total ruins. A comparison between the palace in the painting, (plate 1) and the 1773 plan of the church and palace (plate 3), demonstrates that the right wing of the Bishop's Palace is missing in the painting. This right wing adjoins the northern wall of cathedral. The right wing was repaired at some point, because in the plan of 1773 (plate 3), this wing appears intact. Most likely the repair of the Bishop's Palace took place in 1718-1719 at the same time as the cathedral was repaired.

After having examined not only the construction of the facade of the cathedral, the decorations of the cimborrium and the facade, the location of the Socorro Chapel, the earthquake damage in 1689 and 1717, and the repairs in 1718-1719 but also the construction date as well as earth-

\footnotetext{
${ }^{33}$ Annis, The Architecture, p. 54.

${ }^{34}$ Markman, Colonial, p. 152, citing Juarroz, Pardo, Díaz and Villacorta, states that the present palace was started in 1683 and finished in 1711 . The starting date, 1683 , is five years after the 1677 date Moyssen has given the painting, which includes the palace.

${ }^{35}$ See previous foot note.

${ }^{36}$ See previous foot note.
} 
quake damage of the Bishops' Palace next to the cathedral, one must conclude that a new date must indeed be attributed to the oil painting. Its new date is 1718 and the painting shows the reconstruction of the cathedral after the devastating earthquake of 1717.

Because of its new date of 1718 it now becomes possible to identify some of the people who are included in the painting. It may also be possible to determine a reason for the painting being made. The president of the Captaincy General of Guatemala during 1716-1724 was Francisco Rodríguez de Rivas. ${ }^{37}$ This may be the white-haired man located on the balcony of the Capitania. The Bishop during the same period was Juan Bautista Alvarez de Toledo. The president and bishop disagreed on a number of issues. One of these issues was the possible transfer of the capital of Guatemala from Antigua to a new site in the Valle de las Vacas. ${ }^{38}$

The earthquake of 1717 had caused so much damage in Antigua that one third of its citizens had fled the city and the transfer of the capital to another site was seriously discussed. ${ }^{39}$ Included in the group of people that fled the city was the bishop. The bishop was strongly in favor of permanently moving the capital to a new and presumably safer location. The president, however, was against the move and after a long struggle involving the responsibility for the cost of moving the city and founding a new one, the king was consulted. ${ }^{10}$ The king wanted more information as to the state Antiguan construction was in after the earthquake. In 1718 the king decided that Antigua should remain the capital and on April 6,1718, the repairs of the cathedral were begun. The bishop was described by a contemporary source as having been afraid of returning to the Bishop's Palace because of the severe ruin the palace was in. ${ }^{41}$

The bishop's fear caused him to leave the city by October $1717 .^{42}$ Continuing to fear for his safety, the bishop may not have returned to the capital until the spring of 1718. In the key of the painting, number 35 states: "Casas obispales inhabitadas". If the Bishop's Palace was not lived in at the time of painting this painting, Bishop Alvarez may be seen returning to Antigua after his temporary exile. Number 38 in the key states: "Palacio en q abita el Sr. President i Audiencia Rl". The president

${ }^{37}$ Villacorta, Historia, p. 219

${ }^{38}$ Villacorta, Historia, p. 73, and Amerlinck, Las Catedrales, p. 160

${ }^{39}$ Amerlinck, Las Catedrales, $\mathrm{p}_{\mathrm{n}} 162$.

${ }^{40}$ Amerlinck, Las Catedrales, p. 163.

${ }^{41}$ Markman, Colonial, p. 152.

${ }^{42}$ Amerlinck, Las Catedrales, p. 162: on October 14, 1717, the bishop reported to the King about the earthquake form La Chacara. 
had remained in the city and had all along been a strong advocate in favor of keeping Antigua as the capital. The reason behind the painting may then be not only the reconstruction of the cathedral but the return to normal in the capital and with that the return of the bishop. The return to normal may be celebrated by the musicians on top of the vaults and the chiming church bells. Ironically, Antiqua would remain the capital of the Captaincy General of Guatemala for only another 55 years. In 1773 a new earthquake hit the city and this time the capital was permanently moved to the present day capital of Guatemala.

The artist who painted the reconstruction of the third cathedral in 1718 remains unkown. This article has however demonstrated that the painting is not one of the four pantings that the artist Ramirez painted in 1678. Although the exact identity of the artist remains unknown, it may be possible to speculate on the training of the artist. Because of the great number of accurate architectural details rendered in the painting, it apperars likely that the artist had some degree of architectural training or practical knowledge of architecture. The artist must also have been exposed to Northern European paintings or prints because, despite a certain primitive quality, the painting falls in the style of Northern European genre painting.

A final assumption is that the man in black and white in the left entrance to the cathedral is none other than Diego de Porres, the maestro mayor de arquitectura in Antigua since 1703.3 After the earthquake of 1717 the ayuntamiento in Antigua commissioned Porres, the maestro mayor de obras of the cathedral, to examine the damage to the cathedral. ${ }^{44}$ The man tentatively identified as Porres in the painting appears to be an integral part of the reconstruction of the cathedral. This can be deduced from his frontal and isolated position in the left entrance. Yet his function seems to be supervisory: he is not participating in the physical act of construction surrounding him. The importance of Diego de Porres and his contribution to the architecture of colonial Antigua Guatemala is well established. Porres was in charge of the reconstruction of the cathedral in 1718 and it is quite likely that the artist would have wanted to include him in his panting of the 1718 reconstruction of the cathedral of the Captaincy General of Guatemala.

The presence of the painting in Central America, rather than in Europe, its large size as well as the fact that it is an oil painting rather than a small

\footnotetext{
${ }^{43}$ Markman, Colonial, p. 61 .

${ }^{44}$ Markman, Colonial, p. 62.
} 
drawing, suggest that the painting was important as a commemorative document and was not intended as an architectural report to the royal court. The subject matter and contents of the key indicate instead that the raison d'être of the painting was to document the construction of the vaults in the cathedral of Antigua in $1718 .^{45}$

\footnotetext{
${ }^{45}$ Many changes happened to the cathedral after the painting was made. The tower in the rear was taken down and replaced by the Socorro Chapel. At this time the Cabildo also must have received its second bay. In the painting the Cabildo has only one bay; the Sagrario had four additional bays constructed, either for the first time or as replacement for the four bays which may have come down in 1717. The Sacr istan's House was enlarged to include a second story and a patio, and the windows of the transept on the southern side were removed, as was the wall along the side of the block. The dedication of many chapels was changed to different saints. The left, or southern, wing of the Archbishop's Palace was replaced. The proportions of the central part of the facade were changed and the two missing towers replaced. The central nave vaults were lowered, even though the clerestory was retained. The Captaincy General was replaced with a new structure, the fountain and the Plaza Mayor was replaced and a lonja added in front of the cathedral. All of these changes ocurred between 1718 and 1773. In the 19th century, the two first rows of bays going north-south and the Sagrario were made into the parish church of San José At this point, the clerestory of the central nave must have been removed in the front part of the cathedral and the media naranja, the spherical true dome, of the Sagrario was lowered
} 
APPENDIX

The architectural key, placed in the upper left corner of the painting, plate 1 , reads as follows:

1. Capilla Real.

2. Nave Processional.

3. Capilla Mayor.

4. Boveda del Cuerpo de la Ygla.

5. Segunda Bobeda.

6. El Cimborrio.

7. Bobeda del Choro.

8. Segunda Bobeda.

9. Bobeda de San Dionisio.

10. Ba. de la Puerta del Perdon.

11. Puerta del Perdon.

12. Sala del Cabildo. Tiene tres bóbedas.

13. Capilla de la Consepsion.

14. Capilla del Sto. Christo.

15. Capilla de Sto. Domingo.

16. Capilla de San Miguel.

17. Bda. de la puerta del crusero.

18. Capilla de S. Franco. de Paula.

19. Capilla de San Estevan.

20. Capilla de N.S. de Guadelupe.

21. Capilla de la Encarnacion.

22. La Sacristia. Tiene tres bobedas.

23. Capilla de Na. Sa. de las Nieves.

24. Capilla de Na. Sa. del Socorro.

25. Capilla de Na. Sa de la Concepcion.

26. Capilla de Sn Juan Bautista.

27. Bobeda de la puerta del crusero que sale a la calle de Pal.

28. Capilla de San Pedro.

29. Capilla de la Coronacion.

30. Capilla del Bautisterio.

31. El sagrario tiene siete bobedas. Las naves procesionales tienen diez bobedas cada una de puerta a puerta. Dos puertas a la Plaza Mayor 
y dos a la calle de Sin Pedro, que son sesenta y dos bobedas por todas. $^{1}$

32. Esta obra q' ba pintada en esta media naranxa es la parte de dentro de la Capilla mayor.

33. Colegiales del Seminario de Na. Señora de la Asunción.

34. Estos indios estan tocando el clarin y caxa a su usanza.

35. Casa obispales inabitadas."

36. Todas las demas bobedas que estan por blanquear as a quitado sus cimbras. ${ }^{3}$

37. Casa del Sacristan Mayor.

38. Palacio en q abita el Sr. Presidente i Audiencia Rl.

${ }^{1}$ Luján Muñoz, omitting part of the text of number 31, published: "El Sagrario. Las naves procicionales tienen 36 bobedas cada una de puerta a puerta. Dos puertas a la Plaza Mayor y a la de S. Pedro que son 62 bobedas." La Plaza " ", fig 1

${ }^{2}$ Moyssén, "Cómo se contruía...", p. 5, omitted the text of number 35 completely. The text of number 35 in his publication is actually the text of number 36 in the key of the painting. There is no number 36 in Moyssen's publication of the key.

${ }^{3}$ See previous foot note. Moyssén omitted this text. 


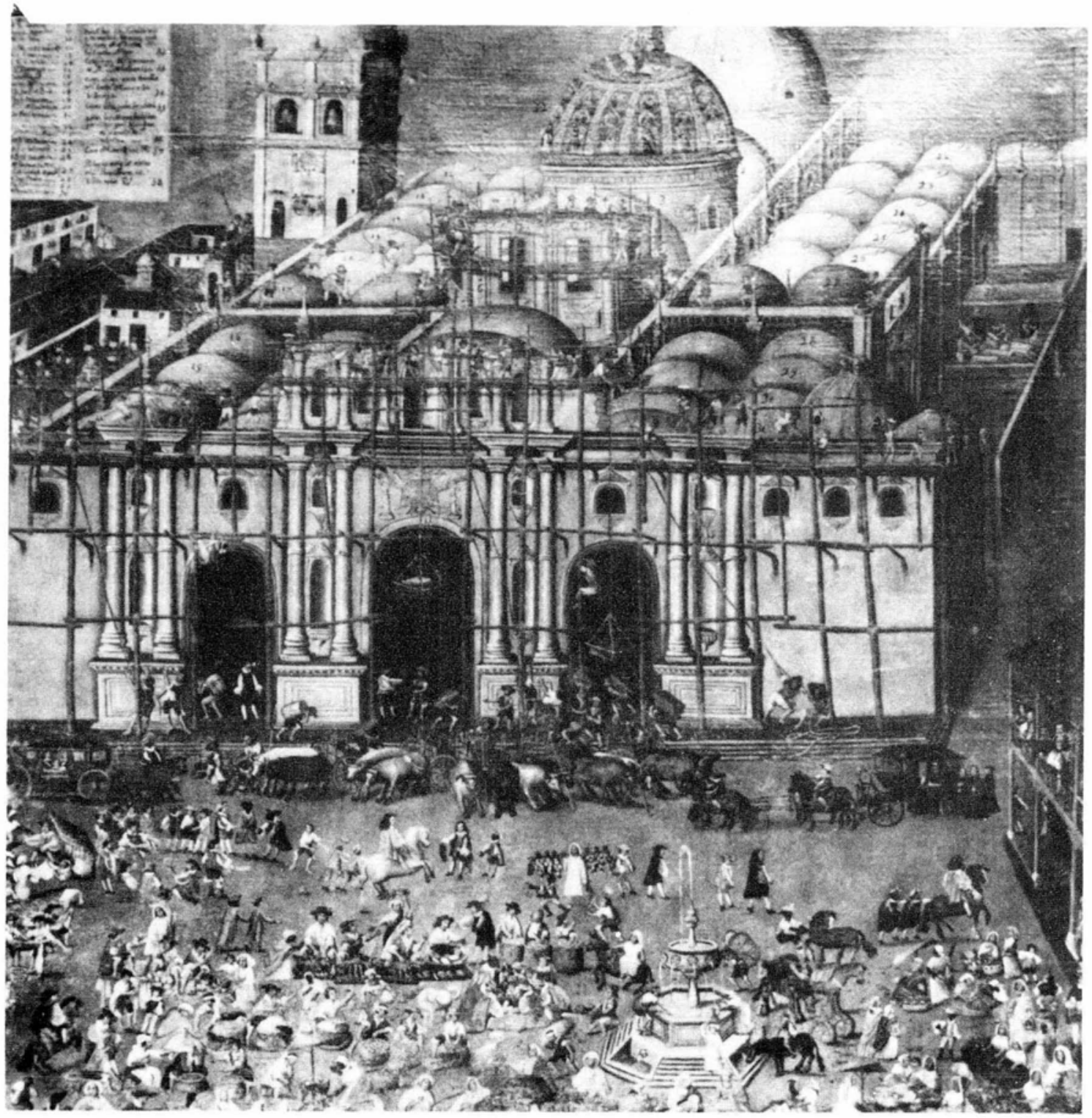

Figura 1. Construction of the Cathedral of Antigua Guatemala, 1718. Oil painting. Photograph by S. D. Markman. Reproduced with the permission of S. D. Markman. Tulane University Latin American Photographic Archive. 


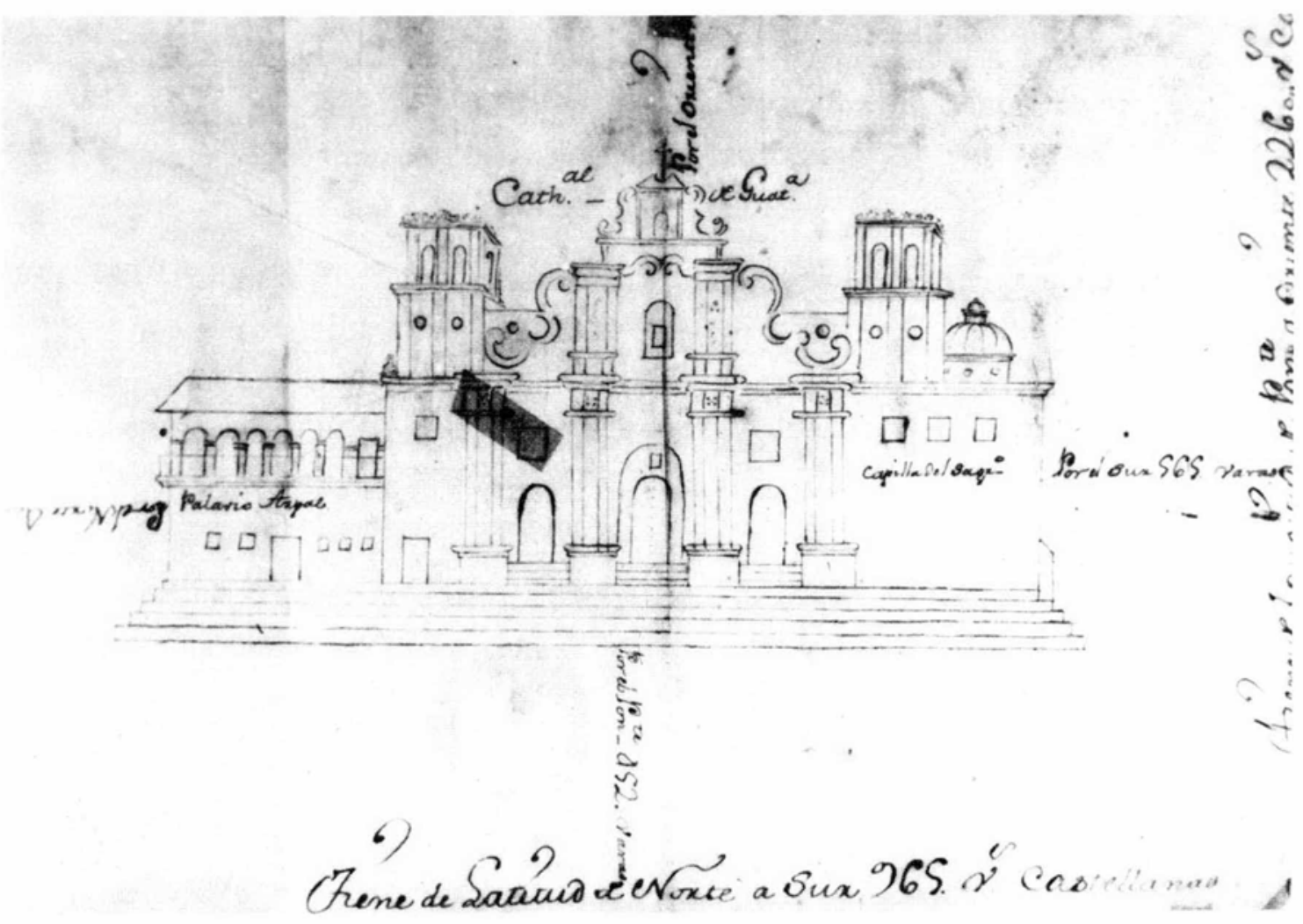

Figura 2. Cathedral, Antigua Guatemala, drawing dated 1784. Reproduced with the permission of S. D. Markman. Photograph by S. D. Markman. Tulane University Latin American Photographic Archive. 


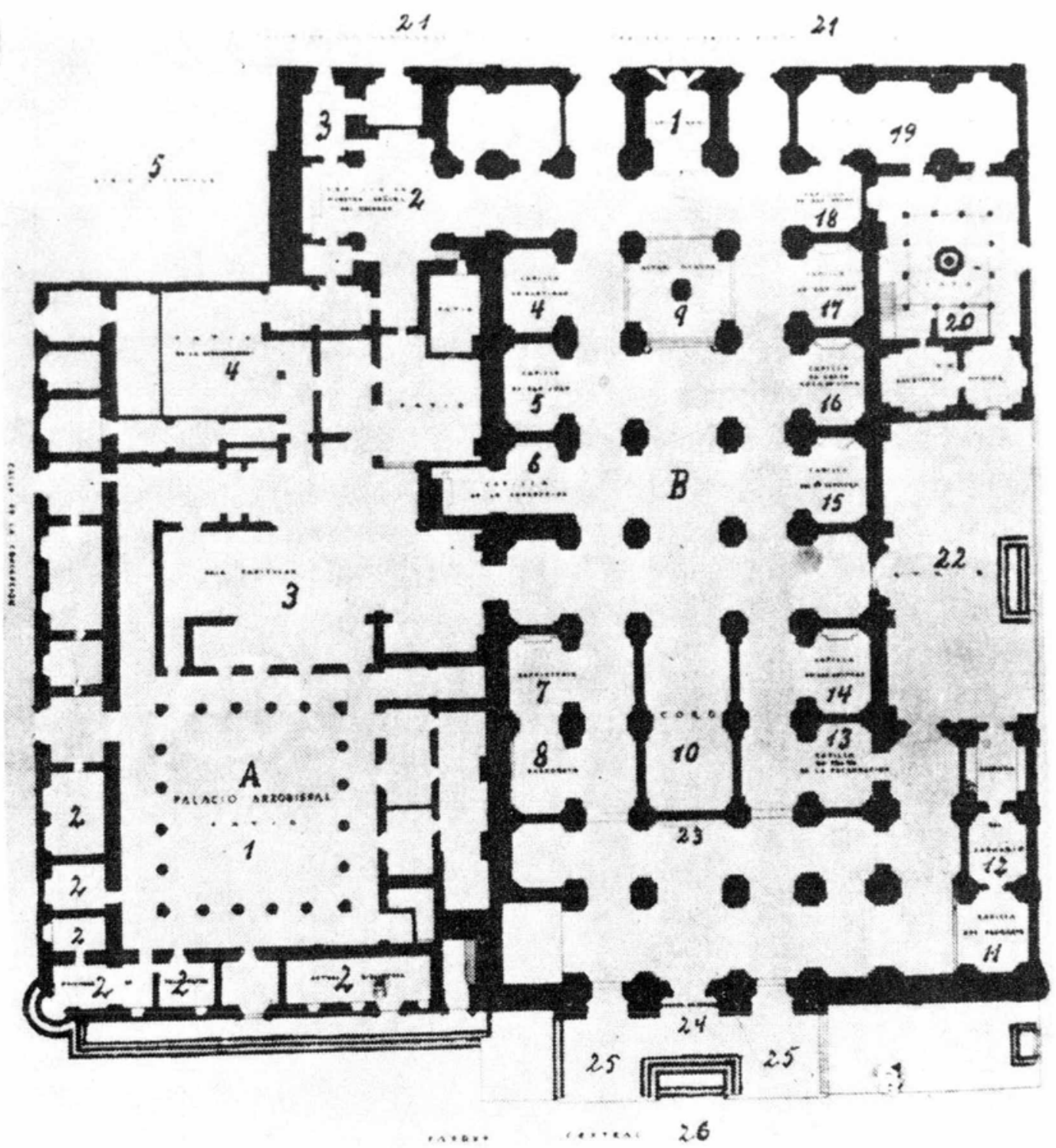

Figura 3. Cathedral, Antigua Guatemala, plan dated 1773. Photograph by S. D. Markman. Reproduced with the permission of S. D. Markman. Tulane University Latin American Photographic Archive. 


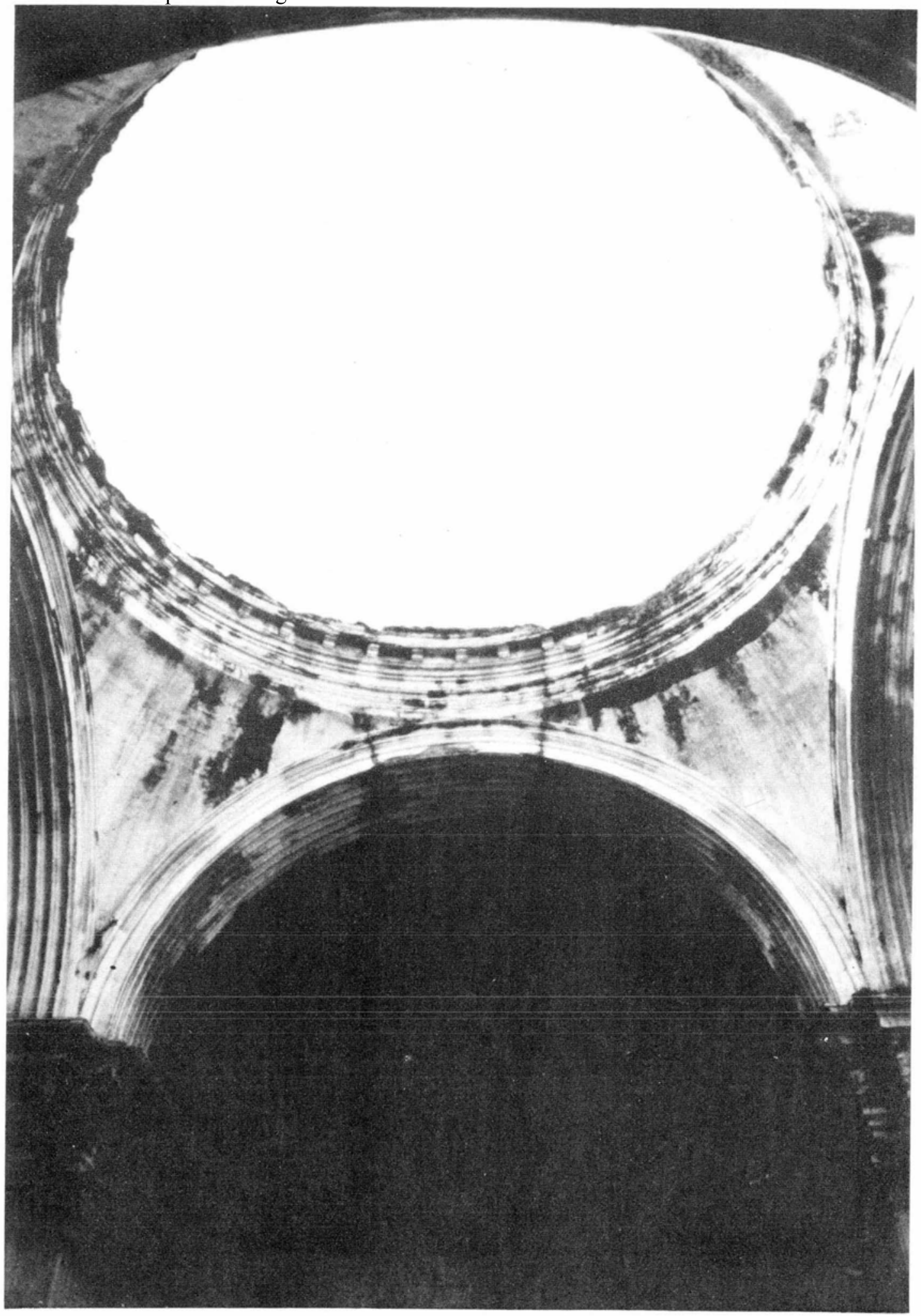

Figura 4. Cathedral, Antigua Guatemala. Socorro Chapel, pendentives and ring of collapsed central dome. Photograph by Eva S. Lamothe. 


\section{BIBLIOGRAPHY}

Amerlinck, María Concepción, Las Catedrales de Santiago de los Caballeros de Guatemala, Universidad Nacional Autónoma de México, Instituto de Investigaciones Estéticas, México, 1981.

AnNis, Verle Lincoln, The Architecture of Antigua Guatemala, 1543-1773, Guatemala, C.A. University of San Carlos, 1968.

Díaz, V.M., La Romántica Ciudad Colonial, Guatemala, Tipografía Nacional, 1927.

Lemoine Vil lacaña, Ernesto, "Historia sucinta de la construcción de la catedral de Guatemala Escrita en 1677 por Don Gerónimo de Betanzos y Quiñones" in Boletín del Archivo General de Nación, no. 3, México: 1961.

Luján Muñoz, Luis, La Plaza de Santiago de Guatemala hacia 1678 "Guatemala C.A. Instituto de Antropología e Historia, Ministerio de Educación. Publicación Especial, no. 3, 1969.

Lu IÁn MuÑoz, Luis, Sintesis biográfica del Maestro Mayor de Arquitectura: Diego de Porres (1677-1977), Guatemala, C.A., Imprenta y Litografía de la Riva Hnos.

Markman, Sidney David, Colonial Architecture of Antigua Guatemala, Philadelphia, The American Philosophical Society, 1966.

Moyssén, Xavier, "Cómo se construía una catedral en el siglo xvı" in Boletín del Instituto Nacional de Antropología e Historia, México: Secretaría de Educación Pública, no. 38, dic. 1969.

Sjoberg Lamothe, Eva, Vaults and Domes in Colonial Antigua Guatemala, ca 1650-1773. M.A. Thesis, Tulane University, U.S.A., 1982.

Viliacorta, D.J., Historia de la Capitania General de Guatemala, Guatemala, 1944. 